\title{
Use of seed treatment with fungicide in control of Colletotrichum truncatum and physiological quality of soybean seeds Glycine max
}

\author{
Vinícius Almeida Oliveira ${ }^{1 * *}$, Lorenzo Paradiso Martins $^{2}$, Rogério Cavalcante Gonçalves ${ }^{2}$, \\ Luíz Paulo Figueredo Benício ${ }^{3}$, Daniella Lima da Costa ${ }^{4}$, Juliane Ludwig ${ }^{5}$
}

\begin{abstract}
The fungus are the main microorganisms present in seeds, is the main cause of deterioration and loss in production. The anthracnose caused by Colletotrichum truncatum associated with soybean seeds as has main vehicle for introduction into the planting areas can be detected in all stages of crop development, from the cotyledons to the end of the cycle, being present in the stems, veins, leaflets and pods. Thus aimed to evaluate the influence of using different products fungicides as seed treatment, where the seeds were inoculated with the pathogenic fungus and treated with the chemicals they take Carbedazim + Fludioxonil + metalaxyl-M and carboxin + thiram. For each fungicide product was two treatments done using the doses recommended by the manufacturer and $75 \%$ of dose. We evaluated health, germination and promote plant (Plant growth, fresh weight and dry weight of root and shoot). This work concludes that the use of fungicide controls significantly seeds infected with Colletotrichum truncatum and presents a significant improvement as the development of structures seedling.
\end{abstract}

Key-words: Germination, plant growth.

\section{Uso de fungicida via tratamento de sementes no controle de Colletotrichum truncatum e na qualidade fisiológica de sementes de soja Glycine Max}

\footnotetext{
RESUMO

Os fungos são os principais microrganismos presentes nas sementes, constituindo a principal causa da deterioração e perdas na produção. A antracnose causada pelo Colletotrichum truncatum associada à soja, tem as sementes como principal veículo de introdução em áreas de plantio podendo ser detectada em todas as fases de desenvolvimento da cultura, desde os cotilédones até o final do ciclo, estando presente nas hastes, nervuras, folíolos e vagens. Assim, objetivou-se avaliar a influência do uso de diferentes produtos fungicidas via tratamento de sementes, onde as sementes foram inoculadas com o fungo patogênico e tratadas com os produtos Carbedazim + Tiram, Fludioxonil + Metalaxyl-M e Carboxina + Tiram. Para cada produto fungicida foi feito dois tratamentos, utilizando a dose indicada pelo fabricante e $75 \%$ da dose. Foram realizadas avaliações de sanidade, germinação, vigor e de crescimento de plantas. O presente trabalho conclui que o uso do fungicida controla significativamente sementes infectadas com Colletotrichum truncatum e apresenta melhora significativa quanto ao desenvolvimento das estruturas das plântulas.

Palavras-chaves: Geminação, crescimento de planta.

*Autor para correspondência.

1,*Doutorando em Agronomia; Universidade Federal de Goiás; CP 13; 74001-970 Goiânia - GO - Brasil; mutamba8@hotmail.com

${ }^{2}$ Eng ${ }^{\circ}$ Agrônomo Mestre em Agroenergia pela Universidade Federal do Tocantins.

${ }^{3}$ Doutorando em Solos e Nutrição de plantas Pela Universidade Federal de Viçosa; 36570-000; Viçosa - MG Brasil.

${ }^{4}$ Instituto Federal de Educação, Ciência e Tecnologia do Tocantins - IFTO;77500-000; Porto Nacional - TO Brasil.

${ }^{5}$ Departamento de Fitopatologia da UNIDERP; 79003-010; Campo Grande - MS - Brasil.
} 


\section{INTRODUCTION}

It is estimated that the average rate of growth of agricultural area in Brazil is $4.7 \%$ per annum over the next decade, one of the world's largest (IICA, 2007).

Dades of the Conab (2010) link the Brazil as one of the largest producers of the world, and the production in the country, in last harvest, was approximately 67,86 million of tones harvested in area of 23,24 million of hectares.

But the economic exploitation of the potential yield (more of the $4000 \mathrm{~kg} / \mathrm{ha}$ ) is hardly achieved, due, among other factors, the onset of disease. Barros (2008) reports that in the last years some disease of soybean have emerged as prominent as the incidence and the damage they have caused, among them anthracnose (Colletotrichum dematium var. truncate). This disease affects all stages of crop development, may cause death of seedlings, necrotic spots on the petioles and leaves, stems and pods (Galli et al., 2007), being present in all the regions of soybean cultivation, and one major problems in soybean areas in the Cerrados.

The seeds are the main vehicle of transmission of this pathogen, one time that fungus can affect the germination and seedling vigor, resulting in lower emergence and the productivity (Patrício, et al., 1991; Sinclair, 1991). Is through of the seeds that microorganism is introduced in new area, survive over the years and spread the plant population as outbreaks of diseases.

The treatment of the seeds is mainly used with the order to allow germination of the infected seeds, controlling pathogens transmitted by seeds and protect them of soil fungi (Henning, et al., 1994). In addition to give protection the seeds, the chemical treatment this provides additional assurance to the establishment of the crop at reduced costs, less than $0,5 \%$ of cost in installation of the crop (Henning, et al., 2005).

Some studies have been performed with the evaluate the efficiency of the treatment of seeds with fungicide in control Colletotrichum truncatum, and being reported significant reductions of pathogen in seeds (Goulart, 2001), and this benefit is reflected increased plant productivity (Goulart, 1998). However, to make such assessments is imperative that there of pathogens in seeds, this fact being provided to accomplish the artificial inoculation of the seeds with the pathogen focus of the study. The artificial inoculations of the soybean seeds with Colletotrichum truncatum can be useful in verifying the location of the pathogen seeds in determinations of its effect on the quality physiological these and in preparation of samples with know effects of the pathogen (Galli et al., 2005).

The analysis of growth is based, fundamentally, in fact to about $90 \%$, in average, of dry matter accumulation in plants throughout is development results of the photosynthetic; allowing to evaluate the growth finish of plant with whole and the contribution of different organs in totally development. Despite the complexity involved in the growth of plants species, the analysis of growth is means a very accurate to avalue the development and measure the contribution of different physiological processes about the plant behavior (Benincasa, 2003) and various works that associate the reduction of accumulation of mass in the reduction of accumulation of mass in the presence of pathogen in seeds (Salustiano et al., 2005; Poletto et al., 2006).

This work has the objective to evaluate the effects about the germination, vigor and growth of plants of the soybean derived of seeds infected artificially with the fungus Colletotrichum truncatum and treated with different fungicides rates via treatment of seeds.

\section{MATERIALS AND METHODS}

The work was conduced during the period of March to June of 2010, in unit lang of university Anhaguera-Uniderp, the city of Campo Grande MS. The work was two steps, the first in laboratory and the second in vegetation's house.

For the treatment of the seeds, these were weighed and packed in transparent plastic bags and were soon added fungicides. After the addition of fungicides, the bags were manually agitated for homogenization of the product and adherence to seeds. The amount of fungicide applied was calculated from the recommendation for $100 \mathrm{~kg}$ of seeds, where it was made of three simple rule for determining the amount of fungicide to be used. It used seeds of soybean of the cultivar CD219RR. The fungicides used are described in the Table 1. 
Table 1. Products and doses used in treatment of the seeds soybean.

\begin{tabular}{llcc}
\hline \multirow{2}{*}{ Fungicides } & \multicolumn{2}{c}{ Dose for $\mathbf{1 0 0 ~ K g}$ of Seeds } \\
\cline { 3 - 4 } & & i.a.* $(\mathbf{g})$ & p.c.** $(\mathbf{m l})$ \\
\hline A & Carbendazin + Thiram & $30+70$ & 200 \\
B & Fludioxonil + Metalaxyl-M & $35+10$ & 100 \\
C & Carboxin + Thiram & $50+50$ & 250 \\
\hline
\end{tabular}

*i.a. - ingredient active; $* * \mathrm{pc}-$ produce commercial.

Isolated from a fungus Colletotrichum truncatum, there was a subculture to Petri dishes containing BDA and placed in a chamber type BOD with $25^{\circ}$ for 15 days to formation of a fungal colony for subsequent seeds inoculation.

For seeds inoculation, this were dipped in a solution of sodium hypochlorite $1 \%$ for three minutes for a disinfection prior. After the disinfection the seeds was dried with filter paper, then were mixed with fungi from the colony established from the isolated of the Colletotrichum truncatum and maintained in contact with the fungus for 48 hours. After the inoculation the seed was separate for treatment and packed in bag of paper.

The seeds treated and uninoculated was subjected to a test of health, that proceeded as follows: The seeds was previously disinfested in solution of sodium hypochlorite the $1 \%$, then distributed in box GERBOX with two sheets of filter paper moistened. After this, the seeds was incubated the a temperature of $22^{\circ} \mathrm{C}$, under the scheme of light, with photoperiod corresponding the 12 hours of light and 12 hours in dark. After seven days of incubated, was made the evaluation of the microorganisms present in seeds, with the astereospic microscope and specialized bibliography (Barnett \& Hunter, 1999). After the identification was calculated the percentage of seeds contaminated by each gender in each treatment fungal. For the test of health were used four repetitions of 100 seeds for each treatment. The treatment were T1 - seeds untreated; T2 Carbendazin + Thiram; T3 - Fludioxonil + Metalaxyl $-\mathrm{M}$ and T4 - Carboxin +Thiram.

At the analysis of laboratory was measured the germination and the index of emergency.

For the test of germination were used eight treatments with four repetitions of 50 seeds and the treatments: T0 - (Seeds untreated); T1 (Seeds inoculated untreated); T2 - (Fungicide A $75 \%$ of dose recommended); T3 - (Fungicide A
$100 \%$ of dose recommended); T4 - (Fungicide B 75\% of dose recommended); T5 - (Fungicide B $100 \%$ of dose recommended); T6 - (Fungicide C $75 \%$ of dose recommended) and $\mathrm{T} 7$ - (Fungicide C $100 \%$ of dose recommended). The seeds were placed for germinate in germination paper "germitest" previously moistened in water on volume corresponding the 2,5 times the weight of dry paper. After the seeds were taken the germinator with temperature constant of $25^{\circ} \mathrm{C}$.

The number of seeds germinated were evaluate daily for seven days, and considered germinated the seeds that obtained radical protusion greater than $2 \mathrm{~mm}$. End of seventh day was accomplished the calculation of percentage of seeds germinateds. For the index of speeds of emergence, used the methodology of coefficient speeds described for Maguire (1962).

In test conducted vegetation`s home were evaluate the following variables: index of plant growth, root length, shoot length and mass dry of shoot and root.

The test was conducted in pots filled with a oxisol red dystrophic (Embrapa, 1999). The soil of vessels was corrected with limestone dolomitic, as the recommendations of analysis chemical of soil. After the correction of soil, each vessel received $20 \mathrm{mg} \cdot \mathrm{dm}^{3}$ of $\mathrm{N} ; 200 \mathrm{mg} \cdot \mathrm{dm}^{3}$ of $\mathrm{P}$ and $100 \mathrm{mg} \cdot \mathrm{dm}^{3}$ of $\mathrm{K}$ and $10 \%$ of volume of land manure of corral. In each vessel were planted three seeds, ten days after the plantations was accomplished the thinning leaving only plant for vessel. The experiment was conducted to the $25^{\circ}$ day after the plantation.

The index of growth of the plants was evaluate after the plants have reached $50 \%$ of germination. The plants were measures with help of a mare the stem of the plant to the apical meristem. The plants were measure to the 25 days after the plantation (DAP).

For the length of the root, length of shoot, mass dry of soot and mass dry of root. To 25 DAP the 
plants were separate in root and shoot, by of a court accomplished with the scissors in collar height. After, with a ruler, was measurement made of booths the parts for be determinate the length of shoot and the root.

For the variable fresh mass and mass dry of root and of shoot, each one of the parts was placed in a bag's paper, separately, and the same were taken the greenhouse with air circulation, where remained for 96 hours with temperature of $55^{\circ} \mathrm{C}$. after, were weighed on an analytical balance for determination of weigh in grams.

With exception of test of health, for the other tests, the type of statistical desing used was fully randomized with eight treatment and four repetitions. The data were submitted the analysis of variance and the average submitted to test of Tukey the $5 \%$ of probability used the program SASM - Agri (Canteri et. al., 2001)

\section{RESULTS AND DISCUSSION}

In test of health of seeds there is that, even seeds be of good origin and certifiel, still so, observed the presence of fungi pathogenic associated the same, and that may come to cause damage to production. From the analysis performed, observed the incidence of fungi Fusarium sp., Penicilium sp., Aspergillus sp., Phomopsis sp., Macrophomina sp. Mucor sp., Cladosporium sp., and bacteria in seeds untreated (Figure 1).

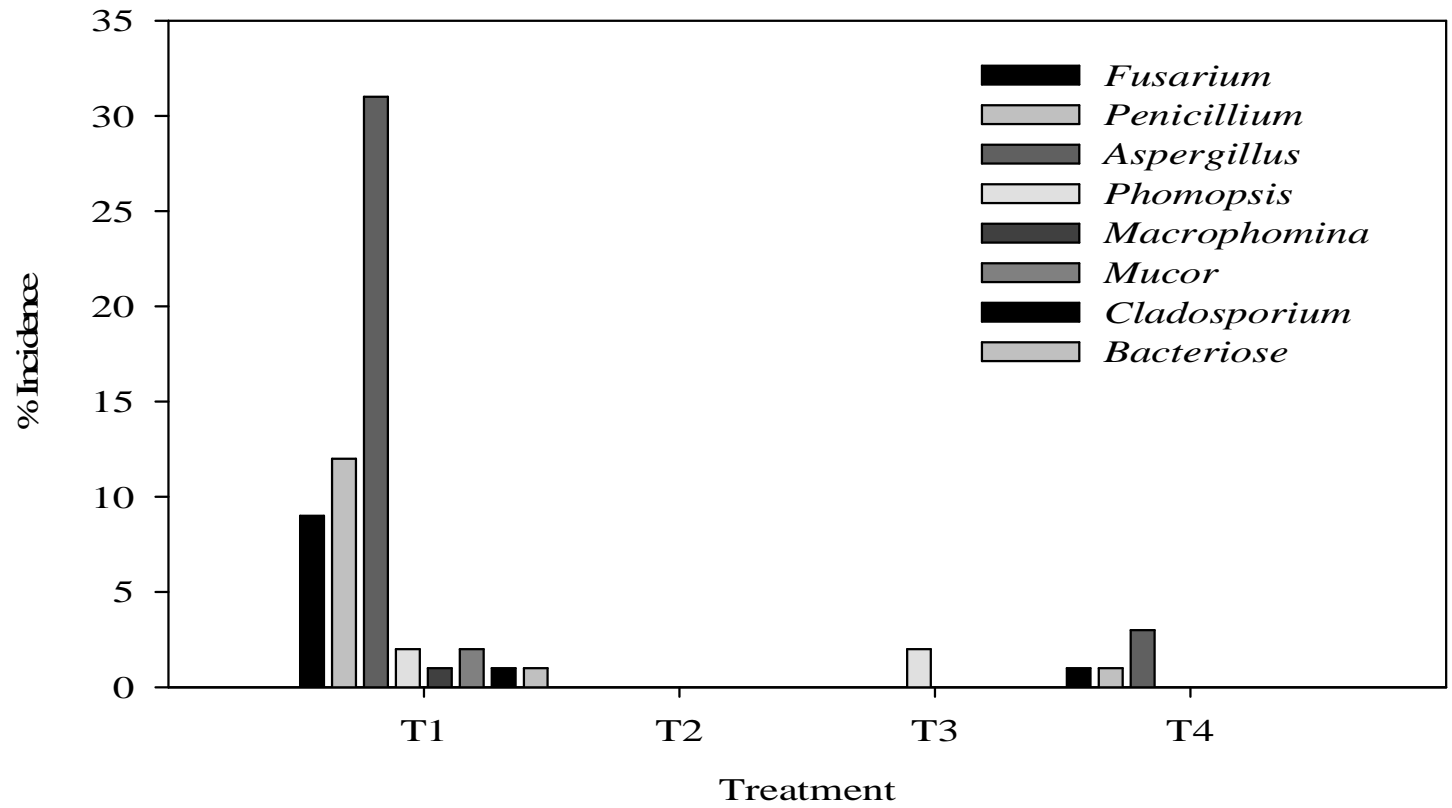

Figure 1 - Incidence of pathogens in soybean seeds treated with differents fungicides.

Among the fungicides evaluated, that showed higher efficiency was the Carbendazin + Thiram (T2), reaching one control of $100 \%$.

On the other hand, the treatment used Fludioxonil + Metalaxyl - M (T3) presented high performance, however was not effective in control of Phomopsis sp., one time that fungi is reported as one of more important in soybean seeds (Henning \& França Neto, 1980). Already the treatment using the Carboxin + Thiran (T4), showed the less efficient, one time that presented only control of Fusarium, Penicillium and Aspergillus (Figure 1).
On that refers to germination of seeds, observed that the pathogen, decreased the germination as well index of velocity of germination seeds, one time that seeds uninoculated for pathogen showed germination significantly superior to inoculated untreated (Table 2). These results reinforce the obtained for Goulart (1997), that reports to be this fungi able of develop quickly at the terms in that test of germination is accomplished can affect the germination os seeds. 
Table 2. Germination in percentage and índex of velocity germination (IVG) of seeds inoculated with Colletotrichum truncatum and treated with 75 and $100 \%$ of dose different fungicide.

\begin{tabular}{llcc}
\hline & \multicolumn{1}{c}{ Treatment } & Germination & IVG \\
\hline T0 & Simple seeds without treatment & $97 \mathrm{a}$ & $21,17 \mathrm{~b}$ \\
T1 & Seeds inoculated without treatment & $57 \mathrm{~b}$ & $13,75 \mathrm{c}$ \\
T2 & Carbendazin + Thiram (75\% of dose) & $96 \mathrm{a}$ & $24,00 \mathrm{ab}$ \\
T3 & Carbendazin + Thiram (100\% of dose) & $99 \mathrm{a}$ & $26,25 \mathrm{a}$ \\
T4 & Fludioxonil + Metalaxyl-M (75\% of dose) & $97 \mathrm{a}$ & $23,25 \mathrm{ab}$ \\
T5 & Fludioxonil + Metalaxyl-M (100\% of dose) & $96 \mathrm{a}$ & $24,25 \mathrm{ab}$ \\
T6 & Carboxin + Thiram (75\% of dose) & $95 \mathrm{a}$ & $23,22 \mathrm{ab}$ \\
T7 & Carboxin + Thiram (100\% of dose) & $93 \mathrm{a}$ & $21,75 \mathrm{~b}$ \\
\hline C.V. & $4,00 \%$ & $5,95 \%$ \\
\hline
\end{tabular}

*Means followed of same letter in column not differ each other for testo f Tukey the 5\% of probability.

Even with respect the germination and the index of velocity germination, was possible observe also that all treatment increased those variables in relative to witness inoculated without any treatment (Table 2), corroborating with the data obtained for Yuyama \& Henning (1997) where the authors claim that treatment of seeds is used mainly with the intended to improve the germination of seeds infected. Important to mention that, the treatment using $100 \%$ of dose Carbendazin +Thiran (T3) possible increases significant in index of velocity germination reaching the $24 \%$ in relative to averages of statistics analysis and tha witness that was not inoculated with Colletotrichum truncatum, demonstrating that product improves the performance physiological of seeds (Pereira et. al., 2009).

On that refers to índex of growth plants, the values mean obteined portray the efficiency of all fungicide in control of main damage associated with the incidence of Colletotrichum truncatum in seeds, that is decrease of emergency seeds (Table 3). This sense, works already demonstrated that use of fungicide applied in seed improved the quality physiological of seeds soybean (Lopes \& Barros, 1997; Yuyama \& Henning, 1997), corn (Von Pinho et al., 1997), cotton (Goulart, 2002) and rice (Teixeira et al., 1997).

Table 3. Index of velocity growth of plants (IVCP) originated in seeds inoculated with Colletotrichum truncatum and treated with 75 and $100 \%$ of dose of different fungicides.

\begin{tabular}{lll}
\hline \multicolumn{2}{l}{ Treatment } & IVCP \\
\hline T0 & Simple seeds without treatment & $4,74 \mathrm{ab}$ \\
T1 & Seeds inoculated without treatment & $1,29 \mathrm{~b}$ \\
T2 & Carbendazin + Thiram (75\% of dose) & $5,40 \mathrm{a}$ \\
T3 & Carbendazin + Thiram (100\% of dose) & $5,96 \mathrm{a}$ \\
T4 & Fludioxonil + Metalaxyl-M (75\% of dose) & $6,54 \mathrm{a}$ \\
T5 & Fludioxonil + Metalaxyl-M (100\% of dose) & $6,07 \mathrm{a}$ \\
T6 & Carboxin + Thiram (75\% of dose) & $6,16 \mathrm{a}$ \\
T7 & Carboxin + Thiram (100\% of dose) & $6,42 \mathrm{a}$ \\
\hline C.V. & $29,67 \%$ \\
\hline
\end{tabular}

*Means followed of same letter in column not differ each other for test of Tukey the $5 \%$ of probability.

To evaluate the final height of plants and the root length, again is observed the effect negative of pathogen associate to seeds, and that seeds treated showed more of $100 \%$ increment in both variables (Table 4). This event may associated to bigger protection of plants to some stress occurred among the seeding and evaluation of test, on time that condition may be aggravated case the treatment of seeds with fungicides not accomplished because to fact of seeds infected/contaminated with pathogens are more subject losses (Machado, 2000), leading reduction of growth plants, as observed in this work. 
Table 4. Length of shoot and the roots plants originated of seeds inoculated with Colletotrichum truncatum and treated with 75 and $100 \%$ of dose of different fungicides.

\begin{tabular}{llcc}
\hline & \multicolumn{1}{c}{ Treatment } & \multicolumn{2}{c}{ Length (cm) } \\
\cline { 3 - 4 } & & Shoot & Root \\
\hline T0 & Simple seeds without treatment & $7,25 \mathrm{ab}$ & $19,30 \mathrm{a}$ \\
T1 & Seeds inoculated without treatment & $2,25 \mathrm{~b}$ & $11,00 \mathrm{~b}$ \\
T2 & Carbendazin + Thiram (75\% of dose) & $9,00 \mathrm{a}$ & $20,25 \mathrm{a}$ \\
T3 & Carbendazin + Thiram (100\% of dose) & $8,25 \mathrm{a}$ & $22,00 \mathrm{a}$ \\
T4 & Fludioxonil + Metalaxyl-M (75\% of dose) & $9,00 \mathrm{a}$ & $19,62 \mathrm{a}$ \\
T5 & Fludioxonil + Metalaxyl-M (100\% of dose) & $8,62 \mathrm{a}$ & $21,75 \mathrm{a}$ \\
T6 & Carboxin + Thiram (75\% of dose) & $9,37 \mathrm{a}$ & $20,25 \mathrm{a}$ \\
T7 & Carboxin + Thiram (100\% of dose) & $9,37 \mathrm{a}$ & $19,00 \mathrm{a}$ \\
\hline C.V. & $31,22 \%$ & $27,32 \%$ \\
\hline
\end{tabular}

*Means followed of same letter in column not differ each other for test of Tukey the 5\% of probability.

On that refers the fresh mass of roots, the treatment that said in relation to witness that not received treatment, was utilized $100 \%$ of dose of fungicide, however, this not varied other treatment, except of treatment using $100 \%$ of dose Carboxin + Thiram (T7). To evaluate the fresh mass of shoot, any of fungicides showed significantly different each other, however, the treatment using $100 \%$ of dose Carboxin + Thiram showed same to treatment whose seeds were inoculated, but untreated (Table 5).

Table 5. Fresh mass of shoot and plants roots originated of seeds inoculated with Colletotrichum truncatum and treated with 75 and $100 \%$ of dose of different fungicides.

\begin{tabular}{llcc}
\hline \multirow{2}{*}{\multicolumn{1}{c}{ Treatment }} & \multicolumn{2}{c}{ Freshmass (g) } \\
\cline { 3 - 4 } & & Shoot & Root \\
\hline T0 & Simple seeds without treatment & $1,96 \mathrm{a}$ & $1,22 \mathrm{ab}$ \\
T1 & Seeds inoculated without treatment & $0,29 \mathrm{~b}$ & $0,08 \mathrm{c}$ \\
T2 & Carbendazin + Thiram (75\% of dose) & $2,66 \mathrm{a}$ & $1,26 \mathrm{ab}$ \\
T3 & Carbendazin + Thiram (100\% of dose) & $2,74 \mathrm{a}$ & $2,23 \mathrm{a}$ \\
T4 & Fludioxonil + Metalaxyl-M (75\% of dose) & $1,91 \mathrm{a}$ & $1,21 \mathrm{ab}$ \\
T5 & Fludioxonil + Metalaxyl-M (100\% of dose) & $2,57 \mathrm{a}$ & $1,64 \mathrm{ab}$ \\
T6 & Carboxin + Thiram (75\% of dose) & $2,25 \mathrm{a}$ & $1,63 \mathrm{ab}$ \\
T7 & Carboxin + Thiram (100\% of dose) & $1,70 \mathrm{ab}$ & $0,97 \mathrm{bc}$ \\
\hline C.V. & $32,71 \%$ & $37,30 \%$ \\
\hline
\end{tabular}

*Means followed of same letter in column not differ each other for testo f Tukey the $5 \%$ of probability.

About to accumulation of dry mass for root, observed the superiority provided for treatment using $100 \%$ of dose of Carbendazin + Thiram (T3), showing statistically same to treatment using $100 \%$ of fungicide Fludioxonil + Metalasyl-M (T5). Already, concerning the accumulation of dry mass of shoot, any of treatment differed significantly each other, however, the treatment in which was used $100 \%$ of dose of Carboxin + Thiram (T7) showed same to treatment whose seeds were inoculated, but untreated (Table 6). Such results may be credited to fact of fungicide have provided the control of fungi that deteriorate the seedling, as observed for Oliveira et al. (1993) in corn and Teixeira (1997) in rice. 
Table 6. Dry mass of shoot and plants roots originated of seed inoculated with Colletotrichum truncatum and treated with 75 and $100 \%$ of dose of different fungicides.

\begin{tabular}{llcc}
\hline \multirow{2}{*}{ Treatment } & \multicolumn{2}{c}{ Drymass (g) } \\
\cline { 3 - 4 } & & Shoot & Root \\
\hline T0 & Simple seeds without treatment & $0,25 \mathrm{a}$ & $0,09 \mathrm{bc}$ \\
T1 & Seeds inoculated without treatment & $0,04 \mathrm{~b}$ & $0,01 \mathrm{c}$ \\
T2 & Carbendazin + Thiram (75\% of dose) & $0,35 \mathrm{a}$ & $0,10 \mathrm{~b}$ \\
T3 & Carbendazin + Thiram (100\% of dose) & $0,36 \mathrm{a}$ & $0,21 \mathrm{a}$ \\
T4 & Fludioxonil + Metalaxyl-M (75\% of dose) & $0,26 \mathrm{a}$ & $0,11 \mathrm{~b}$ \\
T5 & Fludioxonil + Metalaxyl-M (100\% of dose) & $0,34 \mathrm{a}$ & $0,12 \mathrm{ab}$ \\
T6 & Carboxin + Thiram (75\% of dose) & $0,29 \mathrm{a}$ & $0,10 \mathrm{~b}$ \\
T7 & Carboxin + Thiram (100\% of dose) & $0,24 \mathrm{ab}$ & $0,07 \mathrm{bc}$ \\
\hline C.V. & 31,52 & 38,47 \\
\hline
\end{tabular}

*Means followed of same letter in column not differ each other for test of Tukey the 5\% of probability.

Leading in account the variables that determine the potential germinal and physiological of seeds, observed that both agree with Nunes (2006), and the author observed there is effect of fungicide about the germination of seeds, beyond the production of plants more stretching of root, at the same time in which found more growth of shoot, so, fungicide could act as bioactivators and induce the production of crop regulators increasing, the activity enzymatic and allowing the expression of roots and plant.

\section{CONCLUSIONS}

Among the fungicides evaluated, Cabendazin + Thiram was more efficient showing better performance on control of pathogen.

The treatment of seeds soybean with fungicides generally, provided significant increase on potential germination and physiological of seeds improving the germination of seeds, increasing the plant growth and its vigor.

\section{REFERENCES}

BARNETT, H. L. and HUNTER, B. B. Ilustrated genera of imperfect fungi. Burgess Publishing Company, Minnesota, USA. p. 218, 1999.

BARROS, R. Doenças da cultura da soja. In: Tecnologia e Produção: Soja e Milho 2008/2009. 2008 (Caderno técnico 2008/2009).

BENINCASA, M. M. P. Análise de crescimento de plantas (noções básicas). Jaboticabal: FUNEP, p. 41, 2003.

CANTERI, M. G.; ALTHAUS, R. A., VIRGENS FILHO, J. S.; GIGLIOTI, E. A.; GODOY, C. V.
SASM - Agri: Sistema para análise e separação de médias em experimentos agrícolas pelos métodos Scott - Knott, Tukey e Duncan. Revista Brasileira de Agrocomputação, v. 1, n. 2, p. 1824, 2001.

CONAB- Companhia Nacional de Abastecimento. Acompanhamento de safra brasileira: grãos, quarto levantamento, janeiro 2010 / Companhia Nacional de Abastecimento - Brasília, 2010.

EMBRAPA - Empresa Brasileira De Pesquisa Agropecuária. Sistema Brasileiro de Classificação de Solos. P. 412, 1999.

GALLI, J. A.; PANIZZI, R. C.; VIEIRA, R. D. Colletotrichum dematium var. truncata e Phomopsis sojae na qualidade sanitária e fisiológica de sementes de soja. Summa Phytopathologica, v. 33, n. 1, p. 40-46, 2007.

GALLI, J. A.; PANIZZI, R. C.; FESSEL, S. A.; SIMINI, F.; FUMIKO, I. Efeito de Colletotrichum dematium var. truncata e Cercospora kikuchii na germinação de sementes de soja. Revista Brasileira de Sementes, v. 27, n. 1, p. 182-189, 2005.

GOULART, A. C. P. Fungos em sementes de soja: detecção e importância. EMBRAPACPAO, Dourados. p. 58, 1997.

GOULART, A. C. P. Doenças associadas às sementes. Correio agrícola. Jan-Jun, p.12-15, 2001. 
GOULART, A. C. P. Tratamento de sementes de soja com fungicidas: recomendações técnicas. (Circular Técnica, 8). EMBRAPA-CPAO, Dourados. P. 32, 1998.

GOULART, A. C. P. Efeito do tratamento de sementes de algodão com fungicidas no controle do tombamento de plântulas causado por Rhizoctonia solani. Fitopatologia brasileira, v. 27, n. 1, p. 399-402, 2002.

HENNING, A. S. and FRANÇA NETO, J. B. Problemas na avaliação da germinação de sementes de soja com alta incidência de Phomopsis sp. Revista Brasileira de Sementes, v. 2, n. 3, p. 9-22, 1980.

HENNING, A. A.; CATTELAN, A. J.; KRZYZANOWSKI, F. C.; FRANÇA NETO, J. B.; COSTA, N. P. Tratamento e inoculação de sementes de soja. EMBRAPA-CNPSo, Londrina. p. 6, 1994.

HENNING, A. A. Patologia e tratamento de sementes: noções gerais. EMBRAPA- CNPSo, Londrina. P. 52, 2005.

INSTITUTO INTERAMERICANO DE COOPERA-ÇÃO PARA A AGRICULTURA IICA. Informe nacional da situação e das perspectivas da agricultura/2007: Brasil, 2007. Disponível em: <http://www.iica.org.br/Docs/Noticias/IICAdivulg aDocumentosRefletemAgriculturaBrasil_Informe NacionalBrasil2007.pdf $>$. Acesso em: 03 de mar. 2009.

LOPES, M. E. B. M. and BARROS, B. C. Eficiência de fungicidas no controle de fungos em sementes de soja (Glycine $\max$ (L.) Merrill). Revista de Agricultura, v. 72 , n. 1, p. 85-98, 1997.

MACHADO, J. C. Patologia de sementes: significado e atribuições. In: Carvalho, N.M., Nakagawa, J. Sementes: ciência, tecnologia e produção. 4 Ed. Jaboticabal, p. 522-588, 2000.

MAGUIRE, J. D. Speed of germination aid in selection and evaluation for seedling and vigor. Crop Science, Madison, v. 2, n. 2, p. 176177, 1962.
NUNES. J. C. Bioativador de plantas, Revista Seeds News, v. 3, n. 5, p; 30-31, 2006.

OLIVEIRA, J. A.; MACHADO, J. C.; VIEIRA, M. G. G. C. Qualidade sanitária e desempenho de sementes de milho com manchas apicais. Revista Brasileira de Sementes, v. 15, n. 1, p. 101-104, 1993.

PATRICIO, F. R. A.; BORIN, R. B. R. G.; ORTOLANI, D. B. Patógenos associados a sementes que reduzem a germinação e vigor. In: Menten, J. O. M. Patógenos em sementes: detecção, danos e controle químico. Piracicaba, p. 137-60, 1991.

PEREIRA, C. E.; OLIVEIRA, J. A.; MARQUES ROSA, M. C.; OLIVEIRA, G. E.; COSTA NETO, J. Tratamento fungicida de sementes de soja inoculadas com Colletotrichum truncatum. Ciência Rural, v. 39, n. 9, p. 2390-2395, 2009.

POLETTO, I.; MUNIZ, M. F. B.; CECONI, D. E.; SANTIN, D.; WEBER, M. N. D.; BLUME, E. Zoneamento e identificação de Fusarium spp. causador de podridão-de-raízes em plantios de erva mate (Ilex paraguariensis A. St.-Hil.) na região do Vale do Taquarí-RS. Ciência Florestal, v. 16, n. 1, p. 1-10, 2006.

SALUSTIANO, M. E.; MACHADO, J. C.; PITTIS, J. E. Patogenicidade de Alternaria helianthi (HANSF.) e Alternaria zinniae (PAPE) ao girassol a partir de sementes. Revista Brasileira de Sementes, v. 27, n. 1, p. 38-143, 2005.

SINCLAIR, J. B. Latent infection of soybean plants and seeds by fungi. Plant Disease, v. 75, n. 3, p. 220-224, 1991.

TEIXEIRA, E. A.; FILIPPI, M. C.; PRABHU, A. $S$. Eficiência relativa dos fungicidas sistêmicos, no tratamento de sementes para o controle da brusone nas folhas de arroz. Revista Brasileira de Sementes, v. 19, n. 2, p. 179-184, 1997.

VON PINHO, E. V. R.; CAVARIANI, C.; ALEXANDRE, A. D.; MENTEN, J. O. M.; MORAES, M. H. D. Efeitos do tratamento fungicida sobre a qualidade sanitária e fisiológica de sementes de milho (Zea maysL.). Revista 
Brasileira de Sementes, v. 17, n. 1, p. 23-28, 1995.

YUYAMA, M. M. and HENNING, A. S. Avaliação de thiabendazole e thiram no controle dos principais fitopatógenos em sementes de soja. Revista Brasileira de Sementes, v. 19, n. 2, p. 266-269, 1997. 